International Journal of Current Microbiology and Applied Sciences

ISSN: 2319-7706 Volume 6 Number 6 (2017) pp. 95-100

Journal homepage: http://www.ijcmas.com

Original Research Article

https://doi.org/10.20546/ijcmas.2017.606.010

\title{
Effect of Organic Inorganic Bio Fertilizer and Seed Inoculation on Soil Properties, Growth and Yield of Maize (Zea mays L.) Var. Hybrid MM-2255
}

\author{
Pinky Goyal*, Narendra Swaroop and Tarence Thomas
}

Department of Soil Science and Agricultural Chemistry, Sam Higginbottom University of

Agriculture, Technology and Sciences- 211007 Allahabad, U.P., India

*Corresponding author

\section{A B S T R A C T}

A field experiment was conducted during kharif season 2016-17 to study the "Effect of organic, inorganic, bio-fertilizer and seed inoculation on soil properties, growth and yield of maize (Zea may L.) Var. hybrid MM-2255" on Crop Research Farm Department of Soil

\section{Keywords}

Soil nutrients,

Yield attributes,

Azotobacter,

FYM,

Nitrogen.

Article Info

Accepted:

04 May 2017

Available Online:

10 June 2017
Science and Agricultural Chemistry, Naini Agricultural Institute, Allahabad. The design applied for statistical analysis was carried out with $3 \times 2 \times 2$ factorial randomized block design having three factors with three levels of nitrogen 50,75 , and $100 \% \mathrm{ha}^{-1}$, two level of FYM and Azotobacter 0, 100\% respectively. The best treatment was T11-N2F1 A1 (@ $100 \%$ nitrogen $\mathrm{ha}^{-1}+100 \%$ FYM and Azotobacter) that showed the significant increase on enrichment of soil fertility status. Nitrogen, FYM and Azotobacter in combination resulted in a slight Increase in $\mathrm{pH} 7.50, \mathrm{EC} 0.36 \mathrm{dSm}^{-1}$. In post soil combination of nitrogen, FYM and Azotobacter fertilizers observations were resulted in significant increase in organic carbon $0.73 \%$, particle density $2.85 \mathrm{~g} / \mathrm{cc}$, bulk density $1.30 \mathrm{~g} / \mathrm{cc}$, porespace $55.91 \%$, water holding capacity $51.32 \%$ and available $\mathrm{N} 330.5 \mathrm{~kg} \mathrm{ha}^{-1}$, available $\mathrm{P} 32.76 \mathrm{~kg} \mathrm{ha}^{-1}$, available $\mathrm{K} 212.88 \mathrm{~kg} \mathrm{ha}^{-1}$. Significant increase in case of nitrogen $\left(\mathrm{kg} \mathrm{ha}^{-1}\right)$, FYM $\left(\mathrm{kg} \mathrm{ha}^{-1}\right)$ Azotobacter $\left(\mathrm{kg} \mathrm{ha}^{-1}\right)$ in treatment combination T11 -N2 F1 A1 (@ 100\% nitrogen ha ${ }^{-1}+$ $100 \%$ FYM ha ${ }^{-1}$ and $100 \%$ Azotobacter). The maximum cost benefit ratio was recorded 1:2.73 and maximum net return (Rs. 63689.3) ha ${ }^{-1}$ and maximum yield (45.58 $\mathrm{q} \mathrm{ha}^{-1}$ ) in treatment combination T11 -N2 F1 A1 (@100\% nitrogen $\mathrm{ha}^{-1}+100 \% \mathrm{FYM} \mathrm{ha}^{-1}$ and 100 $\%$ Azotobacter).

\section{Introduction}

Maize is one of the important cereal crops in the world agricultural economy both as food grains for human and fodder and feed for cattle and poultry. Maize grain contains about $72 \%$ starch, $10 \%$ protein, $4.8 \%$ oil, $5.8 \%$ fiber, $3.0 \%$ sugar and $1.7 \%$ ash (Choudhary, 1993). Along with this, it is rich in vitamin A, vitamin $\mathrm{E}$, nicotinic acid, riboflavin and contains fairly high phosphorus than rice and sorghum. Its fodder and hay contains 7-10\% protein, $15-36 \%$ fiber, 2.09 to $2.62 \%$ ether extract, $\quad 0.42-0.70 \%$ calcium, $\quad 0.28-0.29 \%$ phosphorus, $0.45 \%$ magnesium, $1.34 \%$ potassium and $56 \%$ carbohydrate. Therefore, it has very nutritive fodder and hay. Besides food grain, fodder and feed, it has prime importance in textile, starch and dye industries.

In India, area and production is 9.2 million per hectare and 24.17 million tones with productivity 2.56 tons per hectare (DMR, 
Annual report 2014-15). In Uttar Pradesh, the area and production is 0.71 million per hectare and 1275 million tones with productivity of $1791 \mathrm{~kg} \mathrm{ha}^{-1}$. (Department of Agriculture, Govt. of UP 2014-15).

\section{Integrated nitrogen management on yield and uptake of nutrients by maize}

The treatments includes supply of nitrogen through inorganic with distillery yeast sludge (DYS), farm yard manure (FYM) and press mud (PM) which contain $1.45 \% 0.58 \%$ and $1.12 \%$ of nitrogen, respectively. Calculated quantity of nitrogen was applied to all eleven treatments with $\mathrm{P}$ and $\mathrm{K}$ as common application. The highest $\mathrm{N}\left(285 \mathrm{~kg} \mathrm{ha}^{-1}\right)$ uptake was recorded in the treatment receiving $100 \%$ recommended dose of nitrogen (RDN) through fertilizer. Significantly higher available nitrogen (286 $\mathrm{kg} \mathrm{ha}^{-1}$ ) was recorded in the treatment with $100 \%$ RDN through DYS at the harvest of crop. Significantly higher available P $(35.7 \mathrm{~kg}$ $\mathrm{ha}^{-1}$ ) was recorded in the treatment receiving $100 \%$ RDN through FYM, whereas K availability did not show marked differences among the treatments at harvest. The high uptake values resulted in high maize yield (Hebsur et al., 2009).

Effect of organic and inorganic sources of nutrient alone and in combination on growth, quality and yield of fodder maize

Application of recommended dose of fertilizer coupled with farm yard manure has recorded highest green and dry matter yield of maize. Substitution of N through FYM to the extent of 25 percent (and remaining 75 percent through urea+50 $\mathrm{kg} \mathrm{P}+50 \mathrm{~kg} \mathrm{~K}$ ) was recorded the best treatment amongest different combination of $\mathrm{N}$ through FYM and urea (73.3 $\mathrm{q} \mathrm{ha}^{-1}$ of dry matter and $278.7 \mathrm{qha}^{-1}$ green fodder yield). Similarly the quality parameters like dry matter content, crude fat, crude protein, nitrogen free extract etc. shows significant difference with the sources of $\mathrm{N}$ through FYM and urea (Bhagade et al., 2008).

Effect of nitrogen with and without Azotobacter inoculation on yield and nutrient uptake by maize crop

Grain yield increased with increasing levels of nitrogen and maximum grain yield of 4.3 $\mathrm{mg} \mathrm{ha}^{-1}$ was obtained by use of $150 \mathrm{~kg} \mathrm{~N}^{-1}$ with FYM @ 5t ha ${ }^{-1}$ and Azotobacter inoculation. Significant uptake of nitrogen, phosphorus and potassium was recorded under application of $150 \mathrm{~N} \mathrm{~kg} \mathrm{ha}^{-1}$ over the control. Protein content in maize grain increased significantly by conjoint use of organic manure and biofertilizers with each level of nitrogen application, over application of each nitrogen level alone (Meena et al., 2013).

\section{Materials and Methods}

A field Experiment was conducted on research farm of Department of Soil Science and Agricultural Chemistry, Sam Higginbottom University of Agriculture, Technology and Sciences Allahabad, U.P. The soil of experimental area falls in order Inceptisol and the experimental field is alluvial in nature. The design applied for statistical analysis was carried out with $3 \times 2 \times 2$ factorial randomized block design having three factors with three levels of N P K @ 50, 75, and 100 percent ha ${ }^{-1}$, two levels of FYM and Azotobacter 0 and $100 \% \mathrm{ha}^{-1}$ respectively. The source of nitrogen, phosphorus, potassium, FYM, Azotobacter as Urea, SSP, MOP, FYM and Azotobacter respectively. Basal dose of fertilizer was applied in respective plots according to treatment allocation unifurrows opened by about $5 \mathrm{~cm}$. depth before sowing seeds in soil at the same time sowing of seeds was sown on 
well prepared beds in shallow furrows, at the depth of $5 \mathrm{~cm}$, row to row distance was maintained at $50 \mathrm{~cm}$ and plant to plant distance was $20 \mathrm{~cm}$, During the course of experiment, observations were recorded as mean values of the data.

\section{Physical and chemical analysis}

Physical analysis pre observations result was done by Bouyoucous hydrometer method. Thetexture sand, silt and clay (\%) was recorded 60, 26, 14 respectively. Bulk density $1.33 \mathrm{~g} / \mathrm{cc}$, particle density $2.45 \mathrm{~g} / \mathrm{cc}$, percentage pore space $49.33 \%$ and water holding capacity $43.50 \%$ was determined by cylinder method. Black (1965), chemical analysis pre observations result of soil viz, $\mathrm{pH}$ 7.39, EC $0.19\left(\mathrm{dS} \mathrm{m}^{-1}\right)$, organic carbon 0.54 $\%$, available nitrogen $290.26\left(\mathrm{~kg} \mathrm{ha}{ }^{-1}\right)$, available phosphorous $25.05\left(\mathrm{~kg} \mathrm{ha}^{-1}\right)$ and available potassium $157.62\left(\mathrm{~kg} \mathrm{ha}^{-1}\right)$ of soil was determined using $\mathrm{pH}$ and $\mathrm{EC}\left(\mathrm{dS} \mathrm{m}^{-1}\right)$ by Jackson (1958) and Walkley and Black (1934) method; alkaline permanganate method (Subbiah and Ashija, 1956) Olsen`s colorimetric method (Olsen et al., 1954) and flame photometric method (Blancher, 1986).

\section{Results and Discussion}

\section{Physical properties}

The results given in table 1 indicate some of the important on physical properties on maize crop (Fig. 1). The interactive effects of nitrogen generally influenced the important in physical properties on maize crop. The effect of nitrogen fertilizer on pore space and bulk density, particle density, water retaining capacity was significant. The maximum particle density (g/cc), bulk density $(\mathrm{g} / \mathrm{cc})$, pore space $(\%)$, water retaining capacity $(\%)$ of after crop harvest soil was recorded 2.66, 1.27, 50.59, 53.56 (@ nitrogen 120 kg ha ${ }^{-1}$ ) respectively, with FYMF1 (FYM@ 10t ha ${ }^{-1}$ ) $2.58,1.24,53.65$ was found to be significant and increasing level of farm yard manure and pore space 50.37 was found non- significant. Azotobacter A1 (@ 200 gm/10kg seed) 49.70, 2.58, 52.91 was found significant and bulk density (\%) 1.26 was found significant. Similar findings were reported by Brar et al., (2015).

\section{Chemical properties of post soil}

During the course of study, it was observed that the highest $\mathrm{pH}\left(\mathrm{dS} \mathrm{m} \mathrm{m}^{-1}\right)$ was recorded is 7.50, treatment T11 (N2F1 A1@ 120 nitrogen kg ha ${ }^{-1}+$ FYM@10t ha ${ }^{-1}+$ Azotobacter@ $200 \mathrm{gm} / 10 \mathrm{~kg}$ seed) and the lowest of 7.12 was recorded with the application of treatment T7 (N2F1 A1@90 nitrogen kg ha ${ }^{-1}$ +FYM@0 t $\mathrm{ha}^{-1}+$ Azotobacter @ $200 \mathrm{gm} / 10 \mathrm{~kg}$ seed). If we compare the $\mathrm{pH}$ of pre sowing soil sample which was 7.39 with that of after crop harvest soil, there is increase in $\mathrm{pH}$ after crop harvest.

Decrease dose of nitrogen, FYM and Azotobacter slightly increasing the soil $\mathrm{pH}$ of the post-harvest soil. The increase in $\mathrm{pH}(\mathrm{dS}$ $\mathrm{m}^{-1}$ ) might be due to higher growth of crops as respiration is more. Respiration evolves carbon dioxide and reacts with water to form carbonic acid in soil. The electrical conductivity $\left(\mathrm{dS} \mathrm{m}^{-1}\right)$, organic carbon $(\%)$, available nitrogen, available phosphorus and available potassium $\left(\mathrm{kg} \mathrm{ha}^{-1}\right)$ of soil after crop harvests: The chemical properties were significantly affected by different treatment combination of nitrogen, FYM and Azotobacter.

The effect of nitrogen, FYM and Azotobacter on organic carbon percent, phosphorus, potassium $\left(\mathrm{kg} \mathrm{ha}^{-1}\right)$, electrical conductivity $\left(\mathrm{dS} \mathrm{m}^{-1}\right)$, available nitrogen significant the maximum chemical properties of after crop harvest soil was recorded electrical conductivity $\left(\mathrm{dSm}^{-1}\right)$, organic carbon $(\%)$, available nitrogen, available phosphorus, available potassium $\left(\mathrm{kg} \mathrm{ha}^{-1}\right)$ 0.189, 0.668, $322.74,31.59,199.85$ respectively. 
Table.1 Effect of different levels of nitrogen, FYM and Azotobacter Chemical properties of soil after harvest mays crop

\begin{tabular}{|c|c|c|c|c|c|c|c|c|c|c|}
\hline $\begin{array}{c}\text { Treatment } \\
\text { combinations }\end{array}$ & $\begin{array}{c}\mathbf{B d}(\mathrm{g} / \\
\mathbf{c c})\end{array}$ & $\begin{array}{c}\text { Pd } \\
(\mathrm{g} / \mathrm{cc})\end{array}$ & $\begin{array}{c}\text { Pore } \\
\text { space } \\
(\%) \\
\end{array}$ & $\begin{array}{c}\text { Water } \\
\text { retaining } \\
\text { capacity }(\%)\end{array}$ & $\begin{array}{l}\text { pH } \\
(1: 2 \\
w / v) \\
\end{array}$ & $\begin{array}{c}\mathrm{EC}(\mathrm{dS} \\
\left.\mathrm{m}^{-1}\right)\end{array}$ & $\begin{array}{l}\text { O.C. } \\
(\%)\end{array}$ & $\begin{array}{l}\text { N (kg } \\
\left.\text { ha }^{-1}\right)\end{array}$ & $\begin{array}{l}\mathbf{P}(\mathbf{k g} \\
\left.\mathbf{h a}^{-1}\right)\end{array}$ & $\begin{array}{l}\text { K(kg } \\
\left.\mathbf{h a}^{-1}\right)\end{array}$ \\
\hline $\mathrm{T}_{0}\left(\mathbf{N}_{\mathbf{0}}+\mathbf{F}_{\mathbf{0}}+\mathbf{A}_{\mathbf{0}}\right)$ & 1.14 & 2.22 & 44.85 & 50.87 & 7.20 & 0.178 & 0.56 & 287.16 & 24.73 & 142.32 \\
\hline $\mathrm{T}_{1}\left(\mathbf{N}_{\mathbf{0}}+\mathbf{F}_{\mathbf{1}}+\mathbf{A}_{\mathbf{0}}\right)$ & 1.24 & 2.52 & 51.84 & 54.00 & 7.31 & 0.188 & 0.60 & 290.21 & 24.71 & 157.10 \\
\hline $\mathrm{T}_{2}\left(\mathbf{N}_{\mathbf{0}}+\mathbf{F}_{\mathbf{0}}+\mathbf{A}_{\mathbf{1}}\right)$ & 1.18 & 2.31 & 49.78 & 52.64 & 7.31 & 0.170 & 0.60 & 294.80 & 27.78 & 157.18 \\
\hline $\mathrm{T}_{3}\left(\mathbf{N}_{\mathbf{0}}+\mathbf{F}_{\mathbf{1}}+\mathbf{A}_{\mathbf{1}}\right)$ & 1.25 & 2.41 & 48.90 & 52.88 & 7.50 & 0.190 & 0.60 & 297.38 & 27.97 & 156.03 \\
\hline $\mathrm{T}_{4}\left(\mathbf{N}_{\mathbf{1}}+\mathbf{F}_{\mathbf{0}}+\mathbf{A}_{\mathbf{0}}\right)$ & 1.20 & 2.73 & 47.78 & 53.28 & 7.37 & 0.197 & 0.54 & 297.50 & 27.16 & 166.57 \\
\hline $\mathrm{T}_{5}\left(\mathbf{N}_{\mathbf{1}}+\mathbf{F}_{\mathbf{1}}+\mathbf{A}_{\mathbf{0}}\right)$ & 1.22 & 2.52 & 49.87 & 52.85 & 7.18 & 0.180 & 0.63 & 309.02 & 28.36 & 172.26 \\
\hline $\mathrm{T}_{6}\left(\mathbf{N}_{\mathbf{1}}+\mathbf{F}_{\mathbf{0}}+\mathbf{A}_{\mathbf{1}}\right)$ & 1.23 & 2.64 & 51.96 & 53.59 & 7.40 & 0.190 & 0.56 & 313.51 & 29.17 & 170.72 \\
\hline $\mathrm{T}_{7}\left(\mathbf{N}_{\mathbf{1}}+\mathbf{F}_{\mathbf{1}}+\mathbf{A}_{\mathbf{1}}\right)$ & 1.25 & 2.64 & 46.94 & 53.70 & 7.12 & 0.188 & 0.56 & 307.70 & 27.09 & 181.83 \\
\hline $\mathrm{T}_{8}\left(\mathbf{N}_{\mathbf{2}}+\mathbf{F}_{\mathbf{0}}+\mathbf{A}_{\mathbf{0}}\right)$ & 1.28 & 2.64 & 52.97 & 52.45 & 7.30 & 0.191 & 0.70 & 319.69 & 31.81 & 191.24 \\
\hline $\mathrm{T}_{9}\left(\mathbf{N}_{\mathbf{2}}+\mathbf{F}_{\mathbf{1}}+\mathbf{A}_{\mathbf{0}}\right)$ & 1.27 & 2.52 & 44.72 & 52.73 & 7.27 & 0.173 & 0.69 & 317.50 & 30.68 & 194.27 \\
\hline $\mathrm{T}_{10}\left(\mathbf{N}_{\mathbf{2}}+\mathbf{F}_{\mathbf{0}}+\mathbf{A}_{1}\right)$ & 1.23 & 2.62 & 48.75 & 57.75 & 7.18 & 0.190 & 0.55 & 323.71 & 31.12 & 200.99 \\
\hline $\mathrm{T}_{11}\left(\mathbf{N}_{2}+\mathbf{F}_{1}+\mathbf{A}_{1}\right)$ & 1.30 & 2.85 & 55.91 & 51.32 & 7.50 & 0.200 & 0.73 & 330.05 & 32.76 & 212.88 \\
\hline F- test & $S$ & $S$ & $\mathrm{~S}$ & $\mathrm{~S}$ & NS & NS & $\mathrm{S}$ & $\mathrm{S}$ & $\mathrm{S}$ & $\mathrm{S}$ \\
\hline S. Em $( \pm)$ & 0.02 & 0.05 & 0.62 & 0.37 & 0.25 & 0.024 & 0.02 & 1.64 & 0.26 & 0.24 \\
\hline C. D. at $5 \%$ & 0.04 & 0.10 & 1.26 & 0.74 & 0.50 & 0.050 & 0.04 & 3.33 & 0.52 & 0.49 \\
\hline
\end{tabular}

Fig.1 Effect of different levels of nitrogen, FYM and Azotobacter on chemical properties of soils after harvest mays crop

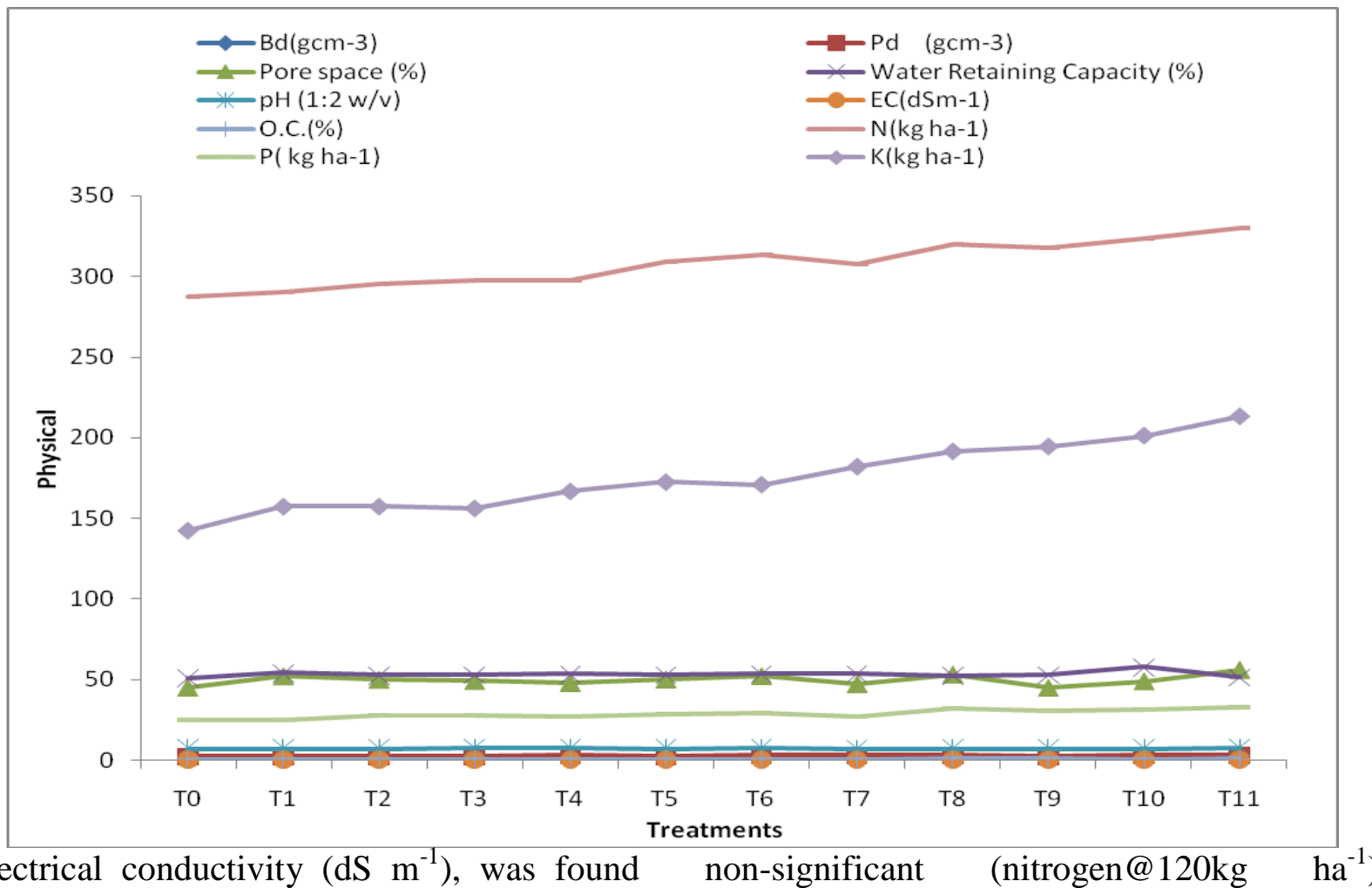

Electrical conductivity $\left(\mathrm{dS} \mathrm{m} \mathrm{m}^{-1}\right)$, was found non-significant (nitrogen@120kg ha $\mathrm{ha}^{-1}$ ) 
respectively, with FYM in level F1 (FYM@ 10t ha ${ }^{-1}$ ) 0.188, 0.601, 311.19, 29.31, 179.94 electrical conductivity $\left(\mathrm{dS} \quad \mathrm{m}^{-1}\right)$ and phosphorus was found non-significant and organic carbon (\%), available potassium $(\mathrm{kg}$ $\left.\mathrm{ha}^{-1}\right)$ and available nitrogen $\left(\mathrm{kg} \mathrm{ha}^{-1}\right)$ available found to be significant, with Azotobacter in level A1 (@ 200 gm/10kg seed) 0.187, 0.636, 308.34, 28.59, 179.94 electrical conductivity (dS $\mathrm{m}^{-1}$ ), was found non-significant and organic carbon percent available phosphorus $\left(\mathrm{kg} \mathrm{ha}^{-1}\right)$ available potassium $\left(\mathrm{kg} \mathrm{ha}^{-1}\right)$ and available nitrogen $\left(\mathrm{kg} \mathrm{ha}{ }^{-1}\right)$ found to be significant. Similar findings were reported by Reddy et al., (2005).

It was concluded from trail that the various levels of integrated nutrients use from different sources in the experiment, the combined application of nitrogen fertilizers N@120 $\mathrm{kgha}^{-1}+$ FYM@ 10t ha ${ }^{-1}$, Azotobacter@200 gm/10kg seed found to be the best in increasing plant height $(183.07 \mathrm{~cm})$, number of leaves per plant (14.40), cob length $(19.11 \mathrm{~cm})$, number of grain per cob(362.87) test weight $(215.20 \mathrm{~g})$ grain yield (45.58 $\mathrm{q} \mathrm{ha}^{-1}$ ) and the physical and chemical properties of soil such as bulk density $(1.30 \mathrm{~g} / \mathrm{cc})$, particle density $(2.85 \mathrm{~g} / \mathrm{cc})$, percent pore space $(55.91 \%)$, water retaining capacity $(51.32 \%)$, EC $\left(0.200 \mathrm{dSm}^{-1}\right), \mathrm{pH}(7.50)$, percent organic carbon $(0.73 \%)$, available $\mathrm{N}\left(330.05 \mathrm{~kg} \mathrm{ha}^{-1}\right)$, available $\mathrm{P}\left(32.76 \mathrm{~kg} \mathrm{ha}^{-1}\right)$, available $\mathrm{K}$ $\left(212.88 \mathrm{~kg} \mathrm{ha}^{-1}\right)$ found that any other treatment combination. The maximum net return (Rs. 63689.3) ha $^{-1}$. Since the result is based on one season experiment, further trial is needed to substantiate the results.

\section{Acknowledgement}

Authors are sincerely thankful to Prof. (Dr.) Gautam Ghosh, Head of Department (Agronomy), Naini Agricultural Institute, for taking their deep interest and encouragement to carry out the research work at Sam
Higginbottom University of Agriculture, Technology and Sciences, Allahabad.

\section{References}

Awad Mohammed, Solaimani Samir G. Al. and El-Nakhlawy Fathy S. (2014) Effect of integrated use of organic and inorganic fertilizers on NPK uptake efficiency by Maize (Zea mays L.), International Journal of Applied Research and Studies (JARS) ISSN: 2278-9480 Volume 3, Issue 7.

Bhagade, H. S., Rajemahadik, V. A. and Akhave, S. R., (2008) Integrated nutrient management studies on growth, quality and yield of fodder maize in konkan region. International Journal of Agricultural Sciences. vol. 4: 2, pp 513515.

Black, C.A. (1965) Methods of soil analysis.Vol.I.Am. Soc. agron. madison, wisconsin, U.S.A.

Brar, Babbu Singh., Singh, Jagdeep, Singh, Gurbir, and Kaur, Gurpreet, Effects of long term application of inorganic and organic fertilizers on soil organic carbon and physical properties in maize-wheat rotation.Journal of Agronomy.vol.2015, 5, 220-238.

Buoyoucos, G.J. (1952) A recalibration of the hydrometer method for making mechanical analysis of soil, 43, 434.

Department of Agriculture, Govt. of UP 2014-15.

Directorate of maize Research (DMR), Annual report 2014-15.

Hebsur, N. S.,Radder, B. M.,Bharamagoudar, T. D. and Pradeep, H. M., (2009) Effect of integrated nitrogen management on available nutrient status and uptake of nutrients by maize (Zea mays). Journal of Ecotoxicology and Environmental Monitoring. 19: 1, 85-90.

Jackson, M. L. (1958) Soil chemical analysis, prentice hall, inc, Englewood cliffe, N.J. 
Meena, M.D., Tiwari1, D.D., Chaudhari, S. K., Biswas, D. R., Narjary, B., Meena, A. L., Meena, B. L. and Meena, R.B.,(2013)Effect of biofertilizer and nutrient levels on yield and nutrient uptake by maize (Zea mays L.)Annals of Agri-Bio Research 18 (2): 176-181

Olsen, S.R., Cole, C.V., Wattnahe, F.S. and Dean, L.A. (1954) Estimation of available phosphorus in soils by extraction with sodium bicarbonate U.S. Dept. Agr.Circ. 939.
Subbiah, B. V. and Asija, G.L. (1956).A rapid procedure for estimation of available nitrogen in soil. Current science 25: 259-263.

Walkey, A. and Black, I. A. (1947) Critical examination of rapid method for determining organic carbon in soils, effect of variance in digestion conditions and of inorganic soil constituents. Soil sci pp.632:251

Wilcox L.V. (1950) Electrical conductivity, amer. Water works assoc. J. 42: pp 775776.

\section{How to cite this article:}

Pinky Goyal, Narendra Swaroop and Tarence Thomas. 2017. Effect of Organic Inorganic Bio Fertilizer and Seed Inoculation on Soil Properties, Growth and Yield of Maize (Zea mays L.) Var. Hybrid MM-2255. Int.J.Curr.Microbiol.App.Sci. 6(6): 95-100. doi: https://doi.org/10.20546/ijcmas.2017.606.010 